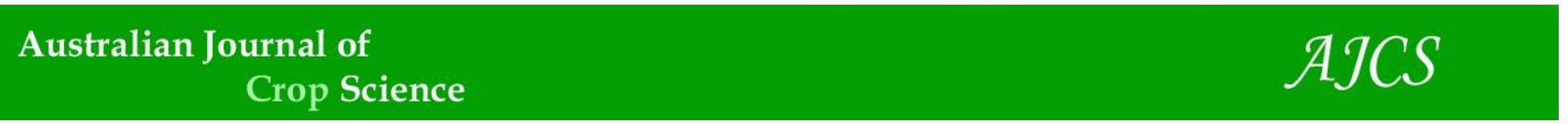

AJCS 15(01):58-66 (2021)

ISSN:1835-2707

doi: 10.21475/ajcs.21.15.01.2602

\title{
Economic feasibility of potato production influenced by intra-row plant spacing under mango-based agroforestry system
}

\author{
Md. Hafiz All Amin ${ }^{1,2}$, Babul Kumar Das ${ }^{1}$, Most. Mottakina Akter ${ }^{3}$, Panu Thainiramit ${ }^{2}$, Warangkana \\ Jutidamrongphan ${ }^{4,5}$, Kua-anan Techato ${ }^{4,5^{*}}$, Tachaya Sangkakool $^{6}$
}

\author{
${ }^{1}$ Agroforestry and Environment, Faculty of Agriculture, Hajee Mohammad Danesh Science and Technology University, Dinajpur- \\ 5200, Bangladesh \\ ${ }^{2}$ Sustainable Energy Management, Faculty of Environmental Management, Prince of Songkla University, Hat Yai, 90110, \\ Songkhla, Thailand \\ ${ }^{3}$ Agriculture Innovation and Management Division, Faculty of Natural Resources, Prince of Songkla University, Hat Yai, 90110, \\ Songkhla, Thailand \\ ${ }^{4}$ Environmental Assessment and Technology for Hazardous Waste Management Research Center, Faculty of Environmental \\ Management, Prince of Songkla University, Hat Yai, 90110, Songkhla, Thailand \\ ${ }^{5}$ Center of Excellence on Hazardous Substance Management (HSM), Bangkok 10330, Thailand \\ ${ }^{6}$ Rajamangala University of Technology Srivijaya, Faculty of Architecture; Hatyai, Songkhla 90112. Thailand
}

\section{"Corresponding author: kuaanan.t@psu.ac.th}

\begin{abstract}
For ensuring the food security and maximum use of land, the potato production under a mango-based agroforestry system is an effective production approach. The purpose of this study was to assess the yield potential and the economic benefits of potato production under a mango-based agroforestry system. The potato tubers were planted in a 10-year-old mango orchard and open field condition. The experiment was laid out following a split plot design with three (3) replications. Potato production system under mango orchard and open field were arranged in main plots $\mathrm{T}_{0}=$ potato sole cropping (control) and $\mathrm{T}_{1}=$ potato under mangobased agroforestry system. On the other hand, potato intra-row plant spacing were in sub-plots $\mathrm{S}_{0}=60 \times 20 \mathrm{~cm}^{2}, \mathrm{~S}_{1}=60 \times 25 \mathrm{~cm}^{2}$ and $S_{2}=60 \times 30 \mathrm{~cm}^{2}$. The data of yield characters of potatoes were investigated. The cost of production, gross \& net return and benefit-cost ratio was calculated for economic analysis. The results show that the closest $\left(60 \times 20 \mathrm{~cm}^{2}\right)$ intra-row plant spacing produced the highest yield while the economic returns from potatoes grown under the mango-based agroforestry system were higher than those derived from cropped grown as a sole crop or potatoes cultivation alone (gross returns US\$3508/ha, net returns US\$1642/ha). Further, the benefit-cost ratio from the combined cultivation of potatoes and mangos was 2.14 , which was $20 \%$ higher than growing potatoes as a sole crop. Thus, the cultivation of potatoes under a mango-based agroforestry system offers a significant financial benefit to farmers while ensuring the sustainable use of vacant space in mango orchards.
\end{abstract}

Keywords: Mangifera indica L.; Monetary potentiality; Multi-production approach; Row spacing; Solanum tuberosum L. Abbreviations: ANOVA_Analysis of Variance; BADC_Bangladesh Agricultural Development Corporation; BARI_Bangladesh Agricultural Research Institute; CEC_Cation Exchange Capacity; DMRT_Duncan's Multiple Range Test; DAP_Days After Planting; MEQ_Milliequivalent; MP_Muriate of Potash; SPSS_Statistical Package for the Social Sciences; TSP_Triple Super Phosphate; US_United States; $\mu$ g_microgram.

Introduction

Bangladesh is a small area of land with high demography having 163.7 million individuals (BBS, 2018). The country chiefly depends on agriculture to meet the food requirements of its inhabitants. However, the current land uses frameworks of farming and forest deficient to fulfil the needs of the 21st century. Basic circumstances, expanding interest for sustenance, human diet, animal feed and wood for construction materials are able to be filled up by customary and non-traditional agroforestry. The issue of maintaining the balance of the environment in association with food security, woody perennials combined with annual crops cultivation is an inevitable production system while keeping up or improving profitability, (Bargali et al., 2004;
Bargali et al., 2009; Pandey et al., 2011; Padalia et al., 2015) strength or in other words sustainability. Multipurpose treebased agroforestry practices are more popular production systems in recent time (Kajal et al., 2015; Amin et al., 2017). It emphasizes the cultivation of agronomic crops together with perennial trees and shrubs (Chowdhury 1997; Miah et al., 2002). Fruit tree-based agroforestry is very popular in tropical and subtropical countries and it brings in a considerable amount of money (Zaman et al., 2016; Rahman et al., 2016; Ali et al., 2018). Potato (Solanum tuberosum L.) has popularity with highly demandable vegetable crops in the world (Solomon-Blackburn and Barker, 2001). It is grown well in a short-day, though it is a $C_{3}$ plant grown in the winter period, requires minimum sunlight (Demagante and 
Vander Zaag, 1988). It is devoured as vegetables contributing alone as much as $54 \%$ of the complete yearly vegetable production of this nation because of its various uses. The production of potato in Bangladesh is $86,03,000$ metric tons with a total area of cultivation of $4,44,000$ hectares. The average yield is 19.37 metric tons per hectare and ranks first among Bangladesh's vegetables in terms of area and output (AIS, 2014). (Dagar and Singh, 2004) reported that potato yield was higher under partial shade when the crops were grown during the second year compared with control (without trees). (Yenagi et al., 2010) was conveyed that higher potato yield was found with Agrade tuber $(45 \mathrm{~cm})$ row spacing while the highest percentage of market yield was recorded with a row spacing of 66 and $75 \mathrm{~cm}$ (Bernik et al., 2002). So, both shade and spacing are the important factors for the production and marketing of the tuber potato. In recent years, farmers are more attracted to establish fruit orchards, mainly mango, due to the maximum benefits within 6 to 7 years, as it is the national tree of Bangladesh. There are more than 100 species of the genus Mangifera that bear edible fruit turned out to be adopted and adjusted all through the tropics and subtropics. It has a significant role in the menu of diet charts among different nations. This heavenly organic product is especially wealthy in supplements, for example, protein, nutrients, fiber, thiamine, ascorbic acid and so on. The organic product is taken as young, processed pickles, juice, bars, iced or hard products. Mango orchard covered 78196 acres of land in fruit plantation with overall production of 304187 metric tonnes in 2017 (BBS, 2017). Day by day mango orchards are increasing, especially in the northern part of Bangladesh. Most of the vacant spaces are fallow in between lines and this is the opportunity to grow vegetables like potatoes on the floor of mango orchards. The information about the production potentiality and profitability of growing potatoes under the mango trees in the northern part of Bangladesh is scant. Focusing on this point, the research work was undertaken to investigate the potatoes potentiality under the young mango orchards maintaining the intra-row plant spacing for both yield and financial benefits from a mango potato-based agroforestry approach.

\section{Results and discussion}

Effect of intra-row plant spacing on potato growth and production potentiality

Intra-row plant spacing is an important factor which focuses on a significant view of various variables like germination to the potato tuber harvest under study. Germination percentage is the most important key issue of crop establishment (Kövendi-Jakó et al., 2017) in the research outcome. The potato tuber germination percentage was significantly varied at 14 and 21 different days after planting (DAP). The highest germination $(38.41 \%$ at 14 DAP and $98.71 \%$ at 21 DAP) was observed in the $S_{2}$ treatment (the widest intra-row plant spacing) and the lowest germination (32.56\% at 14 DAP, and $96.15 \%$ at 21 DAP) was recorded in the $\mathrm{S}_{0}$ treatment (the closest intra-row plant spacing) presented in Fig 1 . The research result was supported by (Akassa et al., 2014) stated that potato top emergence and effective growth and development in association with plants and rows spacing maintaining $70-75$ and $20-30 \mathrm{~cm}$. Potato plant height was observed significantly different in 30,45 , and 60 days after planting (DAP) by the effects of intra-row plant spacing treatments (Table 1 ). The tallest potato plants $(25.89 \mathrm{~cm}, 35.19 \mathrm{~cm}$ and $43.04 \mathrm{~cm}$ at 30,45 , and 60 DAP respectively) were recorded from $\mathrm{S}_{2}$ treatment, whereas the shortest potato plants $(22.20 \mathrm{~cm}, 31.28 \mathrm{~cm}$, and $40.20 \mathrm{~cm}$ at 30,45 , and 60 DAP) were observed from $S_{0}$ treatment the closest intra-row plant spacing. The results received from the research were almost like the findings of (Garrity et al., 1992); (Bussan et al., 2007); (Zamil et al., 2010) and (Getachew et al., 2012). The leaf length of potatoes was significantly varied with different intra-row plant spacing (Table 1). The longest potato leaf $(16.39 \mathrm{~cm})$ was noted in the $S_{2}$ treatment and the shortest potato leaf $(14.45 \mathrm{~cm})$ was measured of $S_{0}$ treatment. Potato leaf breadth was also influenced by different intra-row plant spacing (Table 1 ). The widest potato leaf $(8.28 \mathrm{~cm})$ was determined from the widest plant spacing $\left(\mathrm{S}_{2}\right)$ treatment and the narrow potato leaf $(6.79 \mathrm{~cm})$ was counted in the $\mathrm{S}_{0}$ treatment. The maximum number potato shoot per hill (6.17) was found from $S_{2}$ treatment and the minimum number potato shoot per hill (4.68) was verified from the $S_{0}$ treatment. The potato tuber per hill was counted highest (6.05) from the $S_{0}$ treatment and the lowest number of potato tuber per hill (4.73) was detected from the widest intra-row plant spacing $\left(\mathrm{S}_{2}\right)$ treatment. The maximum weight of potato tuber per hill $(236.20 \mathrm{~g})$ was weighed from the widest intra-row plant spacing $\left(S_{2}\right)$ while, the minimum weight of potato tuber per hill $(228.70 \mathrm{~g})$ was found from the $S_{0}$ treatment the closest intra-row plant spacing. The results obtained from the research were similar to the outcome of (Rahman and Gaffer, 1991); (Sultana and Siddique 1991). They reported that wider spacing increased potato yield per hill, but the highest yield per unit area was obtained from the closer spacing. The results showed that potato tuber yield varied significantly with various intra-row plant spacing (Table 2). Significantly, the highest potato tuber yield (19.33 tonnes per ha) was found in $S_{0}$ treatment conversely the lowest potato tuber yield (16.30 tonnes per ha) was measured from the widest intra-row plant spacing $S_{2}$ treatment. The potato tuber yield taken from the research was often in line with the results of the (Sultana and Siddique 1991); (Zamil et al., 2010) and (Getachew et al., 2012). Arega et al., 2018 mentioned that the highest tuber yield was found in $(75 \mathrm{~cm} \mathrm{x}$ $30 \mathrm{~cm}$ ) intra row spacing. This agreement was highly supported by the present research work. Intra-row plant spacing influences the dry weight of potato tuber also (Table 2). Significantly, the maximum dry weight $(13.98 \mathrm{~g})$ of potatoes was measured from the closest intra-row plant spacing $\mathrm{S}_{0}$ treatment and the minimum dry weight (11.61 $\mathrm{g}$ ) of potatoes was taken from the widest intra-row plant spacing $S_{2}$ treatment. The three intra-row plant spacing made a difference to potato tuber grade significantly (Table 3). The maximum A Grade $(>55 \mathrm{~mm}$ ) potato tuber (1.32) was gathered from the $S_{2}$ treatment, the widest intra-row plant spacing besides the minimum A Grade tuber (0.93) most commonly originated from the $\mathrm{S}_{0}$ treatment. The achievement of the research most related to the outcome of (Yenagi et al., 2010 and Islam et al., 2012). They mentioned that the average size of tuber decreases with a decrease in intra-row plant spacing. The maximum B Grade $(46-55 \mathrm{~mm})$ potato tuber (2.04) was cumulated from the $S_{0}$ treatment, the closest intra-row plant spacing, and the minimum $B$ Grade tuber (1.16) was taken from the $S_{2}$ treatment, the widest intra-row plant spacing. C Grade $(36-46 \mathrm{~mm})$ potato tuber (1.91) was gotten the maximum grade from $S_{0}$ 
treatment the closest intra-row plant spacing consequently the minimum C Grade tuber (1.15) was gained from the $S_{2}$ treatment, the widest intra-row plant spacing. The maximum D Grade $(28-35 \mathrm{~mm})$ potato tuber (1.79) was found from the $S_{2}$ treatment, the widest intra-row plant spacing whereas the minimum Grade-D tuber (1.11) was noted from the $S_{0}$ treatment, the closest intra-row plant spacing, respectively. Ultimately, the maximum E Grade $(<28$ $\mathrm{mm}$ ) potato tuber (1.45) was observed from the $\mathrm{S}_{2}$ treatment and the minimum E Grade tuber (0.99) was obtained from the $S_{0}$ treatment. Potato growing is listed as a high potential food safety and cash crop (Hirpa et al., 2010). Plant density needs to be optimized because it affects seed costs, plant growth, yield and crop quality (Bussan et al., 2007). From the results and discussion, the closest $(60 \times 20$ $\mathrm{cm}^{2}$ ) intra-row plant spacing gave the highest yield and was effectively applicable in the potato production.

\section{Effect of production system on potato growth and production potentiality}

Germination percentage of potato tubers significantly varied at 14 and 21 different days after planting (DAP) due to the practice of different production systems presented in Fig 2 . Significantly, the maximum germination ( $38.39 \%$ at 14 DAP and $98.29 \%$ at $21 \mathrm{DAP}$ ) was observed in potatoes under mango-based agroforestry system $\left(T_{1}\right)$. On the other hand, the minimum germination $(31.91 \%$ at 14 DAP and $96.8 \%$ at 21 DAP) was observed from the potato sole cropping production system $\left(T_{0}\right)$. The maximum germination was obtained due to favourable environmental condition i.e. favourable temperature and moisture taken from the mango-based agroforestry system. Gaur and Pandey (1993) reported that soil temperature and moisture influenced the germination of potato tubers. The height of the potato plant was shown to be statistically significant in the effects of two potato production systems $\left(T_{0}\right)$ and $\left(T_{1}\right)$ highlighted in table 4. At the early stage, $30 \mathrm{DAP}$, the tallest plant $(24.90 \mathrm{~cm})$ originated from control treatment $\left(T_{0}\right)$ potato production in the open field, whereas the shortest plant $(22.92 \mathrm{~cm})$ was received from $T_{1}$ treatment potatoes under the mangobased agroforestry system. In the middle stage at 45 DAP, the tallest plant $(33.98 \mathrm{~cm})$ was gained from $T_{1}$ treatment whereas the shortest plant $(32.09 \mathrm{~cm})$ was found in $T_{0}$ treatment. Finally, at $60 \mathrm{DAP}$, the tallest plant $(43.08 \mathrm{~cm})$ was measured in potato $T_{1}$ treatment whereas the shortest plant $\left(39.85 \mathrm{~cm}\right.$ ) was achieved from $\mathrm{T}_{0}$ treatment (Table 4). The outcome of the research uncovered that the plant tallness expanded with the diminishing of light levels. Plant height relies upon a set of factors, namely accessibility of freshwater, mineral supplements, light amount, light quality and duration, air temperature, a territory of developing space (aerial and edaphic) and plant genetic amendment. Potato developed under the mango-based agroforestry framework was more dynamic than those developed in the control production-meaning, in full daylight conditions. The longest potato leaf $(16.37 \mathrm{~cm})$ was isolated in $\left(T_{1}\right)$ treatment whereas the shortest leaf $(14.39 \mathrm{~cm})$ was evaluated in the control treatment $\left(T_{1}\right)$. Potato leaf breadth was correspondingly differentiated by mango-based agroforestry system was more vigorous than mono cropping production (Table 4). The widest potato leaf $(8.11 \mathrm{~cm})$ was calculated $T_{1}$ treatment. Conversely, the leaf with minimum breadth $(6.79$ $\mathrm{cm}$ ) was considered in the control treatment of potato $\left(T_{0}\right)$. The eventuality of the result was practically identical to
(Wolf et al., 1990) who narrated that cooler temperature produces larger size leaves that remain photosynthetically active for longer periods. Kirk and Marshall, 1992 detailed that temperature significantly impacts the development and improvement of the potato's shade, leaf appearance, extension, and senescence leaf direction. The maximum number potato shoot per hill (5.92) was found from the $T_{0}$ treatment and the minimum number potato shoot per hill (4.75) was received from $T_{1}$ treatment. The sunlight of the open field supported the production of supplementary photosynthesis follow-on the higher shoot per hills were getting from the control treatment. The diverse production system affected the number of tubers per hill significantly (Table 5). The maximum number potato tubers per hill (6.31) was counted in potato production in the control treatment $\left(T_{0}\right)$. Then again, the minimum number potato tuber per hill (4.57) was taken from the $T_{1}$ treatment. More daylight gave more photosynthesis delivered more carbohydrates gathered in the potato tubers. The statement from (Nandal and Hooda, 2005) announced that the primary development and yield assigning character was accountable for the lower yield of potatoes under poplar-based agroforestry practice. The maximum weight of potato tuber per hill $(241.20 \mathrm{~g})$ was weighed in the control treatment $\left(\mathrm{T}_{0}\right)$ and the minimum weight of potato tuber per hill $(224.71 \mathrm{~g})$ was taken in the $\mathrm{T}_{1}$ treatment. Remarkably, the highest potato tuber yield (20.25 tonnes per ha) was achieved from the control treatment $\left(T_{0}\right)$ whereas the lowest potato tuber yield (18.55 tonnes per ha) was balanced in the $T_{1}$ treatment (Table 5). Limited light (shade) is the most important factor that causes poor performance of understory crops. Kumar and Nandal, 2004 detailed that the potato tubers yield significantly no difference under old eucalyptus-tree-based production system over sole cropping of potatoes. The highest yield was due to the photosynthesis rate that brought higher sustenance ingredients placed in the potato tuber. Significantly, the maximum dry weight ( $14.50 \mathrm{~g})$ was determined in the $T_{1}$ treatment and the minimum dry weight $(11.10 \mathrm{~g})$ of potato was achieved from in the $T_{0}$ treatment. The maximum A Grade $(>55 \mathrm{~mm})$ potato tuber (1.25) was counted in the $T_{0}$ treatment and the minimum Grade $(>55 \mathrm{~mm})$ potato tuber (1.07) was taken from the $\mathrm{T}_{1}$ treatment (Table 6). The maximum B Grade ( $46-55 \mathrm{~mm}$ ) potato tuber (1.63) was gained the $T_{0}$ treatment then the minimum B Grade $(46-55 \mathrm{~mm})$ potato tuber (1.35) was noted from the $T_{1}$ treatment. The maximum $C$ Grade $(36-46 \mathrm{~mm})$ potato tuber (1.66) was calculated in the $T_{0}$ treatment and the minimum C Grade $(36-46 \mathrm{~mm})$ potato tuber (1.33) was found in the $T_{1}$ treatment. The maximum $D$ Grade (28-35 $\mathrm{mm}$ ) potato tuber (1.56) was gotten from the $T_{1}$ treatment while the minimum $D$ Grade $(28-35 \mathrm{~mm})$ potato tuber (1.45) was received in the control treatment $\left(\mathrm{T}_{0}\right)$. The maximum $\mathrm{E}$ Grade $(<28 \mathrm{~mm})$ potato tuber (1.40) was found in the $T_{1}$ treatment and the minimum E Grade $(<28 \mathrm{~mm})$ potato tuber (1.05) was observed in sole cropping of potatoes $\left(T_{0}\right)$.

\section{Interaction effect of intra-row plant spacing and production system on potato growth and production potentiality}

Potato tuber emergence varied significantly at 14 and 21 different days after planting (DAP) by the interaction effect of intra-row plant spacing and production system (Fig 3). Significantly, the highest germination $(42.42 \%$ and $99.53 \%$ at 14 DAP and 21 DAP respectively) was observed from the $\mathrm{T}_{1} \mathrm{~S}_{2}$ treatment combination (potato under mango-based 
Table 1. Effect of intra-row plant spacing on plant height, leaf length and breadth, and shoots per hill of potato plants 30,45 and 60 DAP.

\begin{tabular}{|c|c|c|c|c|c|c|}
\hline \multirow{2}{*}{ Treatment } & \multicolumn{3}{|c|}{ Plant height $(\mathrm{cm})$} & \multirow{2}{*}{$\begin{array}{l}\text { Leaf } \\
(\mathrm{cm})\end{array}$} & \multirow[t]{2}{*}{ breadth } & \multirow{2}{*}{$\begin{array}{l}\text { No. of shoots } \\
\text { per hill }\end{array}$} \\
\hline & $30 \mathrm{DAP}$ & 45 DAP & 60 DAP & & & \\
\hline $\mathrm{S}_{0}$ & $22.20 c$ & $31.28 \mathrm{~b}$ & $40.20 b$ & $14.45 b$ & $6.79 b$ & $4.68 c$ \\
\hline $\mathrm{S}_{1}$ & $23.65 b$ & $32.64 b$ & 41.16ab & $15.30 \mathrm{~b}$ & $7.27 b$ & $5.16 b$ \\
\hline $\mathrm{S}_{2}$ & $25.89 a$ & $35.19 a$ & $43.04 a$ & $16.39 a$ & $8.28 a$ & $6.17 a$ \\
\hline Level of Significance & $* *$ & $* *$ & $*$ & $* *$ & $* *$ & $* *$ \\
\hline CV (\%) & 3.93 & 3.00 & 4.83 & 3.77 & 5.31 & 3.50 \\
\hline
\end{tabular}

Notes: $\mathrm{S}_{0} \mathrm{~S}_{1}$ and $\mathrm{S}_{2}$ indicate intra-row plant spacings of $60 \times 20 \mathrm{~cm}^{2}, 60 \times 25 \mathrm{~cm}^{2}$ and $60 \times 30 \mathrm{~cm}^{2}$, respectively. Columns with the same letters are not significantly different. Columns with dissimilar letters indicate treatments, which are significantly different based on DMRT. * Significant at $p \leq 0.05$; ${ }^{* *}$ significant at $\mathrm{p} \leq 0.01$. The coefficient of variation (CV) indicates the ratio of the standard deviation (SD) to the mean value.

Table 2. Effect of intra-row plant spacing on yield characteristics of potatoes.

\begin{tabular}{lcccc}
\hline \multirow{2}{*}{ Treatment } & $\begin{array}{c}\text { Number of potato tubers } \\
\text { per hill }\end{array}$ & $\begin{array}{c}\text { Weight of potato tubers } \\
\text { per hill }(\mathrm{g})\end{array}$ & $\begin{array}{c}\text { Yield of potato tubers per } \\
\text { ha (tonnes) }\end{array}$ & $\begin{array}{c}\text { Dry weight } \\
(\mathrm{g})\end{array}$ \\
\hline $\mathrm{S}_{0}$ & $6.05 \mathrm{a}$ & $228.70 \mathrm{~b}$ & $19.33 \mathrm{a}$ & $13.98 \mathrm{a}$ \\
$\mathrm{S}_{1}$ & $5.56 \mathrm{a}$ & $234.00 \mathrm{a}$ & $17.82 \mathrm{~b}$ & $12.74 \mathrm{~b}$ \\
$\mathrm{~S}_{2}$ & $4.73 \mathrm{~b}$ & $236.20 \mathrm{a}$ & $16.30 \mathrm{c}$ & $11.61 \mathrm{c}$ \\
\hline Level of Significance & $*$ & $* *$ & $* *$ & $* *$ \\
$\mathrm{CV}(\%)$ & 10.02 & 0.75 & 2.24 & 3.61 \\
\hline \multicolumn{2}{c}{ Notes: $\mathrm{S}_{0}, \mathrm{~S}_{1}$ and $\mathrm{S}_{2}$ indicate intra-row plant spacings of $60 \times 20 \mathrm{~cm}^{2}, 60 \times 25 \mathrm{~cm}^{2}$ and $60 \times 30 \mathrm{~cm}^{2}$, respectively. Columns with the same letter are not significantly different. Columns with }
\end{tabular}
Notes: $S_{0}, S_{1}$ and $S_{2}$ indicate intra-row plant spacings of $60 \times 20 \mathrm{~cm}$
dissimilar letters indicate treatments, which are different significantly.

Table 3. Effect of intra-row plant spacing on potato tuber grades.

\begin{tabular}{llllll}
\hline \multirow{2}{*}{ Treatment } & \multicolumn{5}{l}{ Mean number of potato tubers per hill by grade } \\
\cline { 2 - 6 } & $\begin{array}{l}\text { A Grade } \\
(>55 \mathrm{~mm})\end{array}$ & $\begin{array}{l}\text { B Grade } \\
(46-55 \mathrm{~mm})\end{array}$ & $\begin{array}{l}\text { C Grade } \\
(36-46 \mathrm{~mm})\end{array}$ & $\begin{array}{l}\text { D Grade } \\
(28-35 \mathrm{~mm})\end{array}$ & $\begin{array}{l}\text { E Grade } \\
(<28 \mathrm{~mm})\end{array}$ \\
\hline $\mathrm{S}_{0}$ & $0.93 \mathrm{~b}$ & $2.04 \mathrm{a}$ & $1.91 \mathrm{a}$ & $1.11 \mathrm{c}$ & $0.99 \mathrm{c}$ \\
$\mathrm{S}_{1}$ & $1.25 \mathrm{a}$ & $1.27 \mathrm{~b}$ & $1.43 \mathrm{~b}$ & $1.61 \mathrm{~b}$ & $1.23 \mathrm{~b}$ \\
$\mathrm{~S}_{2}$ & $1.32 \mathrm{a}$ & $1.16 \mathrm{c}$ & $1.15 \mathrm{c}$ & $1.79 \mathrm{a}$ & $1.45 \mathrm{a}$ \\
\hline Level of Significance & $* *$ & $* *$ & $* *$ & $* *$ & $* *$ \\
$\mathrm{CV}(\%)$ & 9.57 & 2.47 & 0.49 & 0.53 & 0.72 \\
\hline
\end{tabular}

Notes: $S_{0} S_{1}$ and $S_{2}$ indicate intra-row plant spacings of $60 \times 20 \mathrm{~cm}^{2}, 60 \times 25 \mathrm{~cm}^{2}$ and $60 \times 30 \mathrm{~cm}^{2}$, respectively. Columns with the same letter are not significantly different. Columns with dissimilar letters indicate treatments, which differ significantly based on DMRT. * Significant at $p \leq 0.05 \cdot{ }^{* *}$ significant at $p \leq 0.01$. The CV indicates the ratio of the SD to the mean. Bars having similar letters mean treatments do not differ significantly and dissimilar letters mean treatments significantly differ by (DMRT) Duncan's Multiple Range Test.

Table 4. Effect of production system on plant height, leaf length and breadth and shoots per hill of potato plants 30, 45 and 60 DAP.

\begin{tabular}{|c|c|c|c|c|c|c|}
\hline \multirow{2}{*}{ Treatment } & \multicolumn{3}{|c|}{ Plant height $(\mathrm{cm})$} & \multirow{2}{*}{$\begin{array}{ll}\text { Leaf length } \\
(\mathrm{cm}) & \end{array}$} & \multirow{2}{*}{$\begin{array}{l}\text { Leaf } \\
(\mathrm{cm})\end{array}$} & \multirow{2}{*}{$\begin{array}{l}\text { No. of shoots } \\
\text { per hill }\end{array}$} \\
\hline & 30 DAP & 45 DAP & 60 DAP & & & \\
\hline$\overline{T_{0}}$ & $24.90 a$ & $32.09 \mathrm{~b}$ & $39.85 b$ & $14.39 \mathrm{~b}$ & $6.79 b$ & $5.92 a$ \\
\hline $\mathrm{T}_{1}$ & $22.92 \mathrm{~b}$ & $33.98 a$ & $43.08 a$ & $16.37 a$ & $8.11 a$ & $4.75 b$ \\
\hline Level of Significance & $* *$ & $* *$ & $* *$ & $* *$ & $* *$ & $* *$ \\
\hline CV (\%) & 3.93 & 3.00 & 4.83 & 3.77 & 5.31 & 3.50 \\
\hline
\end{tabular}

Notes: $T_{0}$ indicates sole-crop/open field production system (control): $T_{1}$ represents potatoes grown under the mango-based agroforestry production system.

Columns with the same letter are not significantly different. Columns with dissimilar letters indicate treatments which differ significantly based on DMRT.

** Significant at $\mathrm{p} \leq 0.01$. The CV indicates the ratio of the SD to the mean value.

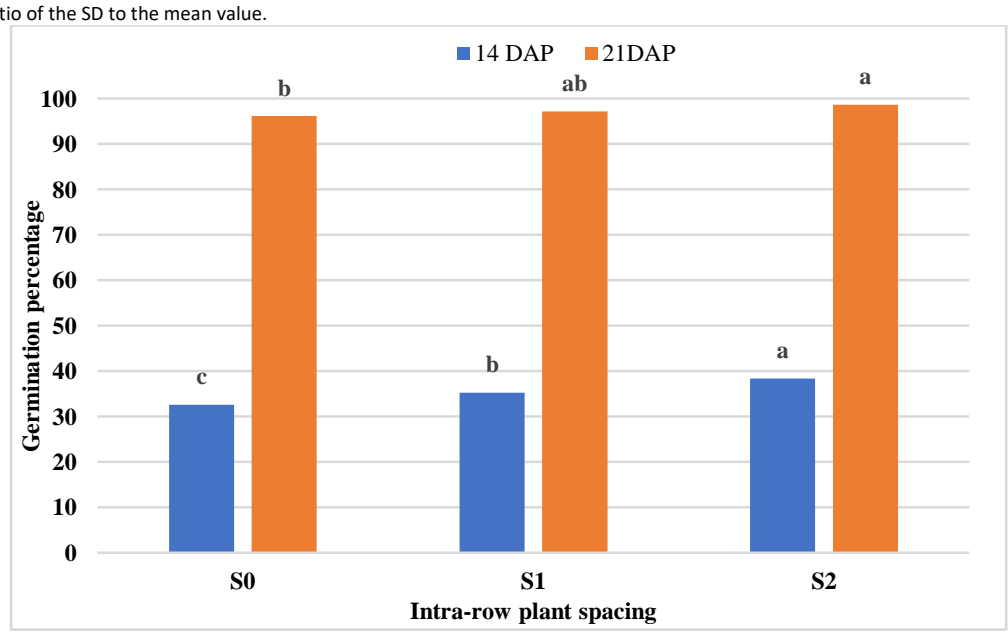

Fig 1. Effect of intra-row plant spacing on the germination (\%) of potatoes at 14 and 21 DAP. Notes: SO, S1 and S2 indicate intra-row plant spacings of $60 \times 20 \mathrm{~cm}^{2}, 60 \times 25 \mathrm{~cm}^{2}$ and $60 \times 30 \mathrm{~cm}^{2}$, respectively. Bars with the same letter are not significantly different; bars with dissimilar letters indicate treatments which significantly differ based on DMRT. 


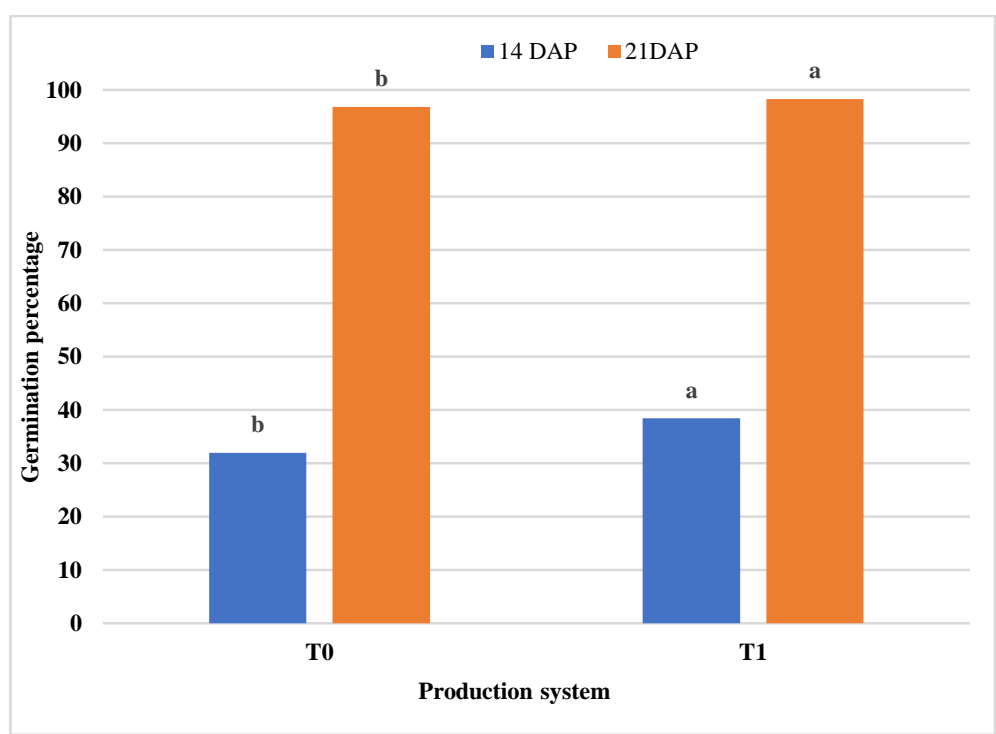

Fig 2. Effect of production system on the germination \% of potatoes at 14 and 21 DAP. Notes: T0 indicates sole-crop/open field production system (control); T1 represents potatoes grown under the mango-based agroforestry production system.nificantly based on DMRT. * Significant at $\mathrm{p} \leq 0.05$; ** significant at $\mathrm{p} \leq 0.01$. The $\mathrm{CV}$ indicates the ratio of the SD to the mean.

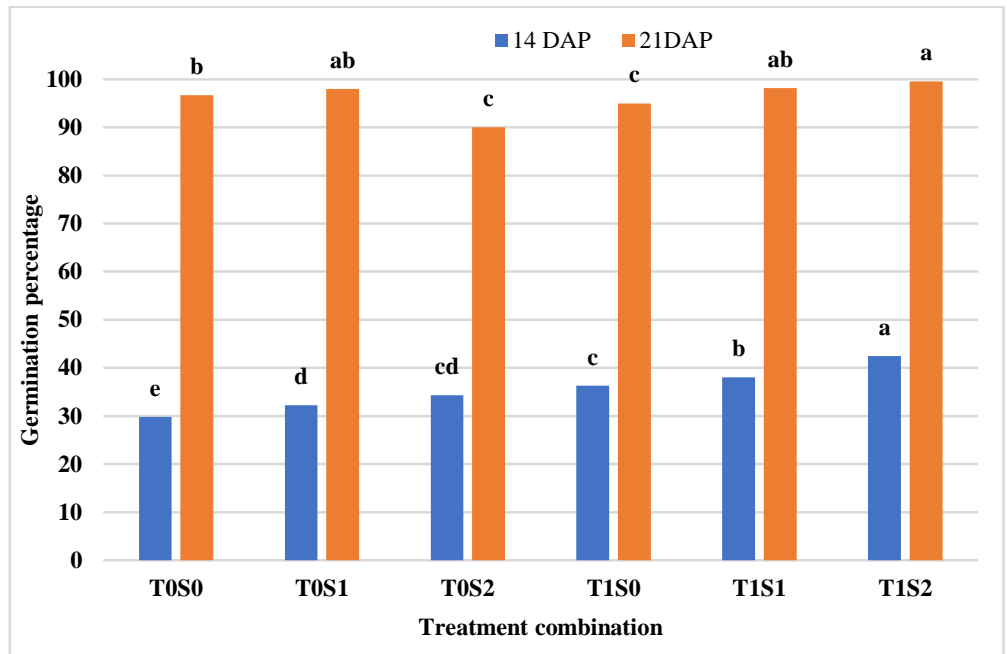

Fig 3. Interaction effect of intra-row plant spacing and production system on germination of potatoes at 14 and 21 DAP.

Notes: TOSO, TOS1 andTOS2, indicate intra-row spacings of $60 \times 20 \mathrm{~cm}^{2}, 60 \times 25 \mathrm{~cm}^{2}$ and $60 \times 30 \mathrm{~cm}^{2}$, respectively, of potatoes under monocropping; T1S0, T1S1 and T1S2 indicate intra-row spacings of $60 \times 20 \mathrm{~cm}^{2}, 60 \times 25 \mathrm{~cm}^{2}$ and $60 \times 30 \mathrm{~cm}^{2}$, respectively, of potatoes under mango trees. Bars with the same letter do not differ significantly. Bars with dissimilar letters indicate treatments that differ significantly based on DMRT.

Table 5. Effect of production system on yield characteristics of potatoes.

\begin{tabular}{|c|c|c|c|c|}
\hline Treatment & $\begin{array}{l}\text { Number of potato } \\
\text { tubers per hill }\end{array}$ & $\begin{array}{c}\text { Weight of potato tubers } \\
\text { per hill }(\mathrm{g})\end{array}$ & $\begin{array}{c}\text { Yield of potato tubers per } \\
\text { ha (tonnes) }\end{array}$ & $\begin{array}{l}\text { Dry weight } \\
\text { (g) }\end{array}$ \\
\hline $\mathrm{T}_{0}$ & $6.31 a$ & $241.20 a$ & $20.25 a$ & $11.10 \mathrm{~b}$ \\
\hline $\mathrm{T}_{1}$ & $4.57 b$ & $224.71 b$ & $18.55 b$ & $14.50 \mathrm{a}$ \\
\hline Level of Significance & $* *$ & $* *$ & $* *$ & $* *$ \\
\hline CV (\%) & 10.02 & 0.75 & 2.24 & 3.61 \\
\hline
\end{tabular}

Table 6. Effect of production system on potato tuber grades.

\begin{tabular}{lccccc} 
& \multicolumn{5}{c}{ Mean number of potato tubers of each grade per hill } \\
\cline { 2 - 6 } Treatment & $\begin{array}{c}\text { A Grade } \\
(>55 \mathrm{~mm})\end{array}$ & $\begin{array}{c}\text { B Grade } \\
(46-55 \mathrm{~mm})\end{array}$ & $\begin{array}{c}\text { C Grade } \\
(36-46 \mathrm{~mm})\end{array}$ & $\begin{array}{c}\text { D Grade } \\
(28-35 \mathrm{~mm})\end{array}$ & $\begin{array}{c}\text { E Grade } \\
(<28 \mathrm{~mm})\end{array}$ \\
\hline $\mathrm{T}_{0}$ & $1.25 \mathrm{a}$ & $1.63 \mathrm{a}$ & $1.66 \mathrm{a}$ & $1.45 \mathrm{~b}$ & $1.05 \mathrm{~b}$ \\
$\mathrm{~T}_{1}$ & $1.07 \mathrm{~b}$ & $1.35 \mathrm{~b}$ & $1.33 \mathrm{~b}$ & $1.56 \mathrm{a}$ & $1.40 \mathrm{a}$ \\
\hline Level of Significance & $* *$ & $* *$ & $* *$ & $* *$ & $*$ \\
$\mathrm{CV}(\%)$ & 9.57 & 2.47 & 0.49 & 0.53 & 0.72 \\
\hline
\end{tabular}

Notes: $T_{0}$ indicates sole-crop/open field production system (control); $T_{1}$ represents potatoes grown under the mango-based agroforestry production system. Columns with the same letter are not significantly different. Columns with dissimilar letters indicate treatments which differ significantly based on DMRT. ${ }^{* *}$ Significant at $p \leq 0.01$.

The $\mathrm{CV}$ indicates the ratio of the SD to the mean value. 
Table 7. Interaction effects of intra-row plant spacing and production system on plant height, leaf length and breadth and number of shoots per hill of potato plants 30,45 and 60 DAP.

\begin{tabular}{|c|c|c|c|c|c|c|}
\hline \multirow{2}{*}{ Treatment } & \multicolumn{3}{|c|}{ Plant height $(\mathrm{cm})$} & \multirow{2}{*}{$\begin{array}{l}\text { Leaf length } \\
(\mathrm{cm})\end{array}$} & \multirow{2}{*}{$\begin{array}{l}\text { Leaf breadth } \\
(\mathrm{cm})\end{array}$} & \multirow{2}{*}{$\begin{array}{c}\text { No. of shoots } \\
\text { per hill }\end{array}$} \\
\hline & 30 DAP & 45 DAP & 60 DAP & & & \\
\hline $\mathrm{T}_{0} \mathrm{~S}_{0}$ & $23.06 \mathrm{bc}$ & $30.58 d$ & $38.65 b$ & $13.40 d$ & $6.09 c$ & $5.31 \mathrm{c}$ \\
\hline $\mathrm{T}_{0} \mathrm{~S}_{1}$ & $24.67 b c$ & $31.63 \mathrm{~cd}$ & $39.48 b$ & $14.57 \mathrm{~cd}$ & $6.57 c$ & $5.75 b$ \\
\hline $\mathrm{T}_{0} \mathrm{~S}_{2}$ & $26.97 a$ & $34.06 \mathrm{~b}$ & 41.41ab & $15.21 b c$ & $7.21 b$ & $6.70 a$ \\
\hline $\mathrm{T}_{1} \mathrm{~S}_{0}$ & $21.33 d$ & $31.98 b-d$ & 41.74ab & $15.50 \mathrm{bc}$ & $7.78 b$ & $4.04 \mathrm{e}$ \\
\hline $\mathrm{T}_{1} \mathrm{~S}_{1}$ & $22.63 c d$ & $33.65 b c$ & $42.83 a b$ & $16.04 b$ & $7.97 b$ & $4.57 d$ \\
\hline $\mathrm{T}_{1} \mathrm{~S}_{2}$ & $24.81 b$ & $36.32 a$ & $44.67 a$ & $17.58 \mathrm{a}$ & $8.86 a$ & $5.65 \mathrm{bc}$ \\
\hline Level of Significance & $* *$ & $* *$ & $* *$ & $* *$ & * & $* *$ \\
\hline CV (\%) & 3.93 & 3.00 & 4.83 & 3.77 & 5.31 & 3.50 \\
\hline
\end{tabular}

Notes: $\mathrm{T}_{0} \mathrm{~S}_{0}, \mathrm{~T}_{0} \mathrm{~S}_{1}$ and $\mathrm{T}_{0} \mathrm{~S}_{2}$, indicate intra-row spacings of $60 \times 20 \mathrm{~cm}^{2}, 60 \times 25 \mathrm{~cm}^{2}$ and $60 \times 30 \mathrm{~cm}^{2}$, respectively, of potatoes grown as a sole crop; $\mathrm{T}_{1} \mathrm{~S}_{0}, \mathrm{~T}_{1} \mathrm{~S}_{1}$ and $\mathrm{T}_{1} \mathrm{~S}_{2}$ indicate intra-row spacings of $60 \times$ $20 \mathrm{~cm}^{2}, 60 \times 25 \mathrm{~cm}^{2}$ and $60 \times 30 \mathrm{~cm}^{2}$, respectively, of potatoes under mango trees. Columns with the same letter are not significantly different. Columns with dissimilar letters indicate treatments which differ significantly based on DMRT. * Significant at $p \leq 0.05 ;{ }^{* *}$ significant at $p \leq 0.01$. The CV indicates the ratio of the SD to the mean.

Table 8. Interaction effect of intra-row plant spacing and production system on the yield characteristics of potatoes.

\begin{tabular}{lccc}
\hline Treatment & $\begin{array}{c}\text { Number of potato } \\
\text { tubers per hill }\end{array}$ & $\begin{array}{c}\text { Weight of potato tubers } \\
\text { per hill }(\mathrm{g})\end{array}$ & $\begin{array}{c}\text { Yield of potato tubers } \\
\text { per ha (tonnes) }\end{array}$ \\
\hline $\mathrm{T}_{0} \mathrm{~S}_{0}$ & $5.45 \mathrm{bc}$ & $236.80 \mathrm{~b}$ & $20.22 \mathrm{a}$ \\
$\mathrm{T}_{0} \mathrm{~S}_{1}$ & $6.49 \mathrm{ab}$ & $242.00 \mathrm{a}$ & $18.42 \mathrm{~b}$ \\
$\mathrm{~T}_{0} \mathrm{~S}_{2}$ & $7.02 \mathrm{a}$ & $244.80 \mathrm{a}$ & $17.63 \mathrm{c}$ \\
$\mathrm{T}_{1} \mathrm{~S}_{0}$ & $4.23 \mathrm{~d}$ & $220.60 \mathrm{~d}$ & $18.43 \mathrm{~b}$ \\
$\mathrm{~T}_{1} \mathrm{~S}_{1}$ & $4.61 \mathrm{~cd}$ & $225.90 \mathrm{c}$ & $11.11 \mathrm{e}$ \\
$\mathrm{T}_{1} \mathrm{~S}_{2}$ & $5.07 \mathrm{~cd}$ & $227.60 \mathrm{c}$ & $17.23 \mathrm{c}$ \\
\hline Level of Significance & $* *$ & $* *$ & $12 \mathrm{f}$ \\
$\mathrm{CV}(\%)$ & 10.02 & 0.75 & $14.97 \mathrm{~d}$ \\
\hline
\end{tabular}

Notes: $\mathrm{T}_{0} \mathrm{~S}_{0}, \mathrm{~T}_{0} \mathrm{~S}_{1}$ andT $\mathrm{S}_{2}$ indicate intra-row spacings of $60 \times 20 \mathrm{~cm}^{2}, 60 \times 25 \mathrm{~cm}^{2}$ and $60 \times 30 \mathrm{~cm}^{2}$, respectively, of potatoes grown as a sole crop; $\mathrm{T}_{1} \mathrm{~S}_{0}, \mathrm{~T}_{1} \mathrm{~S}_{1}$ and $\mathrm{T}_{1} \mathrm{~S}_{2}$ indicate intra-row spacings of $60 \times$ $20 \mathrm{~cm}^{2}, 60 \times 25 \mathrm{~cm}^{2}$ and $60 \times 30 \mathrm{~cm}^{2}$, respectively, of potatoes under mango trees. Columns with the same letter are not significantly different. Columns with dissimilar letters indicate treatments which differ significantly based on DMRT. * Significant at $p \leq 0.05$; ** significant at $p \leq 0.01$. The CV indicates the ratio of the SD to the mean.

Table 9. Interaction effect of intra-row plant spacing and production system on potato tuber grades.

\begin{tabular}{|c|c|c|c|c|c|c|c|}
\hline \multirow[b]{2}{*}{ Treatment } & \multicolumn{7}{|c|}{ Mean number of potato tubers in each grade per hill } \\
\hline & $\begin{array}{c}\text { A Grade } \\
(>55 \mathrm{~mm})\end{array}$ & \multicolumn{2}{|c|}{$\begin{array}{c}\text { B Grade } \\
(46-55 \mathrm{~mm})\end{array}$} & $\begin{array}{c}\text { C Grade } \\
(36-46 \mathrm{~mm})\end{array}$ & $\begin{array}{c}\text { D Grade } \\
(28-35 \mathrm{~mm})\end{array}$ & \multicolumn{2}{|c|}{$\begin{array}{c}\text { E Grade } \\
(<28 \mathrm{~mm})\end{array}$} \\
\hline $\mathrm{T}_{0} \mathrm{~S}_{0}$ & $0.99 \mathrm{~cd}$ & \multicolumn{2}{|c|}{$2.19 a$} & $2.12 \mathrm{a}$ & $1.06 f$ & \multicolumn{2}{|c|}{$0.84 d$} \\
\hline $\mathrm{T}_{0} \mathrm{~S}_{1}$ & $1.35 a$ & \multicolumn{2}{|c|}{$1.40 c$} & $1.64 b$ & $1.54 d$ & \multicolumn{2}{|c|}{$1.10 \mathrm{c}$} \\
\hline $\mathrm{T}_{0} \mathrm{~S}_{2}$ & 1.39a & \multicolumn{2}{|c|}{$1.28 \mathrm{~d}$} & $1.22 \mathrm{c}$ & $1.74 b$ & \multicolumn{2}{|c|}{$1.20 c$} \\
\hline $\mathrm{T}_{1} \mathrm{~S}_{0}$ & $0.87 d$ & \multicolumn{2}{|c|}{$1.88 \mathrm{~b}$} & $1.70 \mathrm{~b}$ & $1.16 \mathrm{e}$ & \multicolumn{2}{|c|}{$1.13 c$} \\
\hline $\mathrm{T}_{1} \mathrm{~S}_{1}$ & $1.10 \mathrm{bc}$ & \multicolumn{2}{|c|}{$1.13 \mathrm{e}$} & $1.21 \mathrm{c}$ & $1.67 \mathrm{c}$ & \multicolumn{2}{|c|}{$1.36 \mathrm{~b}$} \\
\hline $\mathrm{T}_{1} \mathrm{~S}_{2}$ & $1.25 a b$ & \multicolumn{2}{|c|}{$1.04 \mathrm{f}$} & $1.08 \mathrm{~d}$ & $1.83 a$ & \multicolumn{2}{|c|}{$1.70 a$} \\
\hline Level of Significance & $*$ & \multicolumn{2}{|c|}{$*$} & $* *$ & $* *$ & \multicolumn{2}{|c|}{$* *$} \\
\hline CV (\%) & 9.57 & \multicolumn{2}{|c|}{2.47} & 0.49 & 0.53 & \multicolumn{2}{|c|}{0.72} \\
\hline \multicolumn{8}{|c|}{$\begin{array}{l}\text { Notes: } \mathrm{T}_{0} \mathrm{~S}_{0}, \mathrm{~T}_{0} \mathrm{~S}_{1} \text { andT } \mathrm{T}_{0} \mathrm{~S}_{2} \text {, indicate intra-row spacings of } 60 \times 20 \mathrm{~cm}^{2}, 60 \times 25 \mathrm{~cm}^{2} \text { and } 60 \times 30 \mathrm{~cm}^{2} \text {, respectively, of potatoes grown as a sole crop; } \mathrm{T}_{1} \mathrm{~S}_{0}, \mathrm{~T}_{1} \mathrm{~S}_{1} \text { and } \mathrm{T}_{1} \mathrm{~S}_{2} \text { indicate intra-row spacings of } 60 \\
20 \mathrm{~cm}^{2}, 60 \times 25 \mathrm{~cm}^{2} \text { and } 60 \times 30 \mathrm{~cm}^{2} \text {, respectively, of potatoes under mango trees. Columns with the same letter are not significantly different. Columns with dissimilar letters indicate treatmen } \\
\text { which differ significantly based on DMRT. * Significant at } \mathrm{p} \leq 0.05 ;{ }^{* *} \text { significant at } \mathrm{p} \leq 0.01 \text {. The } \mathrm{CV} \text { indicates the ratio of the SD to the mean. }\end{array}$} \\
\hline \multirow[t]{2}{*}{ Treatments } & & \multicolumn{2}{|c|}{ Outcome (US\$/ha) } & \multirow{2}{*}{$\begin{array}{l}\text { Gross } \\
\text { Return } \\
\text { (\$./ha) }\end{array}$} & \multirow{2}{*}{$\begin{array}{l}\text { Total cost of } \\
\text { Production } \\
\text { (\$./ha) }\end{array}$} & \multirow{2}{*}{$\begin{array}{l}\text { Net } \\
\text { Return } \\
\text { (\$./ha) }\end{array}$} & \multirow[t]{2}{*}{$\mathrm{BCR}$} \\
\hline & & Potato tuber & $\begin{array}{l}\text { Mango fruit } \\
\text { tree }\end{array}$ & & & & \\
\hline Open field/sole-cr & $\operatorname{oes}\left(T_{0}\right)$ & 2858.00 & - & 2858.00 & 1600.00 & 1258.00 & 1.78 \\
\hline Potatoes under ma & es $\left(T_{1}\right)$ & 2618.00 & 890.00 & 3508.00 & 1642.00 & 1866.00 & 2.14 \\
\hline
\end{tabular}

Note: Potato price US\$0.14/kg; mango price US\$0.71/kg

agroforestry system with widest intra-row spacing). In contrast, the lowest germination $(29.82 \%$ and $96.67 \%$ at 14 DAP and 21 DAP) was noted in the $\mathrm{T}_{0} \mathrm{~S}_{0}$ treatment combination (potato in sole cropping with closest intra-row spacing). The potato plant height was found statistically different from the interaction effect of intra-row plant spacing and production system (Table 7). At 30 DAP, the tallest plant $(26.97 \mathrm{~cm})$ was recorded in the $T_{0} S_{2}$ treatment combination followed by $\mathrm{T}_{1} \mathrm{~S}_{2}, \mathrm{~T}_{0} \mathrm{~S}_{1}$ and $\mathrm{T}_{0} \mathrm{~S}_{0}$ treatment combinations and the shortest plant $(21.33 \mathrm{~cm})$ was recorded in the $\mathrm{T}_{1} \mathrm{~S}_{0}$ treatment combination. At $45 \mathrm{DAP}$, the tallest plant $(36.32 \mathrm{~cm})$ was received in the $T_{1} S_{2}$ treatment combination followed by $\mathrm{T}_{0} \mathrm{~S}_{2}$ and $\mathrm{T}_{1} \mathrm{~S}_{1}$ treatment combinations and the shortest plant of potato $(30.58 \mathrm{~cm})$ was obtained in the $\mathrm{T}_{0} \mathrm{~S}_{0}$ treatment combination. Significantly, at 60 DAP the tallest plant $(44.67 \mathrm{~cm})$ was achieved in the $T_{1} S_{2}$ treatment combination whereas the shortest plant $(38.65 \mathrm{~cm})$ was observed in the $T_{0} S_{0}$ treatment combination, respectively. The longest leaf (17.58 $\mathrm{cm}$ ) was found in the $T_{1} S_{2}$ treatment combination followed by $T_{1} S_{1}, T_{1} S_{0}$ treatment combinations and the shortest leaf (13.40) was collected in the $\mathrm{T}_{0} \mathrm{~S}_{0}$ treatment combination. The widest leaf $(8.86 \mathrm{~cm})$ was raised in the $\mathrm{T}_{1} \mathrm{~S}_{2}$ treatment combination and the leaf with minimum breadth (6.09) was 
determined in the $\mathrm{T}_{0} \mathrm{~S}_{0}$ treatment combination. The maximum potato shoot per hill (6.70) was raised in the $T_{0} S_{2}$ treatment combination and the minimum potato shoot per hill (4.04) was observed in the $\mathrm{T}_{1} \mathrm{~S}_{0}$ treatment combination (Table 7). The maximum potato tuber per hill (7.02) was reckoned in the $\mathrm{T}_{0} \mathrm{~S}_{2}$ treatment combination followed by $\mathrm{T}_{0} \mathrm{~S}_{1}, \mathrm{~T}_{0} \mathrm{~S}_{0}$ treatment combinations, respectively. Then again, the minimum potato tuber per hill (4.23) was calculated in the $\mathrm{T}_{1} \mathrm{~S}_{0}$ treatment combination. The maximum weight of potato tuber $(244.80 \mathrm{~g})$ was observed in the $\mathrm{T}_{0} \mathrm{~S}_{2}$ treatment combination followed by the $\mathrm{T}_{0} \mathrm{~S}_{1}, \mathrm{~T}_{0} \mathrm{~S}_{0}$ treatment combinations, respectively. Alternatively, the minimum weight of potato tuber $(220.60 \mathrm{~g})$ was gained in $T_{1} \mathrm{~S}_{0}$ treatment combination. The interaction effect of the intrarow plant spacing, and production system significantly inclined the yield of potato tuber (Table 8). Significantly, the maximum potato tuber yield (20.22 tonnes per ha) was found in the $\mathrm{T}_{0} \mathrm{~S}_{0}$ treatment combination (potato in monocropping with $20 \mathrm{~cm}$ intra-row plant spacing) followed by $\mathrm{T}_{1} \mathrm{~S}_{0}, \mathrm{~T}_{0} \mathrm{~S}_{1}$ treatment combinations respectively. In contrast, the minimum potato tuber yield (14.97 tonnes per ha) was obtained in the $\mathrm{T}_{1} \mathrm{~S}_{2}$ treatment combination (potato under mango-based production system with $30 \mathrm{~cm}$ intra-row plant spacing). The maximum dry weight of potato tuber (15.89 g) was noted in the $\mathrm{T}_{1} \mathrm{~S}_{0}$ treatment combination and the minimum dry weight of potato tuber (10.12 g) was weighed in the $\mathrm{T}_{0} \mathrm{~S}_{2}$ treatment combination. The maximum $A$ Grade $\left(>55 \mathrm{~mm}\right.$ ) potato tuber (1.39) was selected in the $\mathrm{T}_{0} \mathrm{~S}_{2}$ treatment combination and the minimum A Grade $(>55 \mathrm{~mm})$ potato tuber (0.87) was brought from the $\mathrm{T}_{1} \mathrm{~S}_{0}$ treatment combination, respectively (Table 9 ). The maximum B Grade (46-55mm) potato tuber (2.19) was observed in the $\mathrm{T}_{0} \mathrm{~S}_{0}$ treatment combination, and the minimum B Grade (46$55 \mathrm{~mm}$ ) potato tuber (1.04) was balanced in the $\mathrm{T}_{1} \mathrm{~S}_{2}$ treatment combination. The highest C Grade (36-46 mm) potato tuber (2.12) was determined in the $\mathrm{T}_{0} \mathrm{~S}_{0}$ treatment combination and the lowest C Grade (36-46 $\mathrm{mm})$ potato tuber (1.08) was logged in the $T_{1} S_{2}$. The maximum D Grade (28-35 mm) potato tuber (1.74) was received in the $\mathrm{T}_{1} \mathrm{~S}_{2}$ treatment combination then the minimum D Grade (28-35 $\mathrm{mm}$ ) potato tuber (1.07) was shown in the $\mathrm{T}_{0} \mathrm{~S}_{0}$ treatment combination. The maximum E Grade $(<28 \mathrm{~mm})$ potato tuber (1.70) was observed in the $T_{1} S_{2}$ treatment combination while the minimum $E$ Grade ( $<28 \mathrm{~mm}$ ) potato tuber (1.70) was recorded in the $\mathrm{T}_{0} \mathrm{~S}_{0}$ treatment combination.

\section{Economic performance of potato production}

The cost of production, gross return and net return of potato as inter-crop in mango-based agroforestry production system and sole cropping were calculated based on local market rates prevailing during experimentation and converted into United States dollars (Table 10). The maximum cost of production (US\$1642.00 per ha) was calculated from the $T_{1}$ treatment potato production under mango tree the agroforestry practice, while the least production cost (US\$1600.00 per ha) was measured from the control treatment $\left(T_{0}\right)$. The maximum return of gross money (US\$ 3508.00 per ha) was achieved from the $T_{1}$ treatment and the minimum return of gross currency (US\$2858.00 per ha) was taken from the $T_{0}$ treatment. Net return was maximum in potato growing under mango-based agroforestry practice $\left(T_{1}\right)$ compared to potatoes in mono farming $\left(\mathrm{T}_{0}\right)$. It was observed that potato under mangobased agroforestry system $\left(T_{1}\right)$ gave the maximum net return (US\$1866.00 per ha). At the same time, the minimum net return (US\$1258.00 per ha) was received from the potato in mono cultivation $\left(T_{0}\right)$. Table 10 indicated that the maximum benefit-cost ratio (2.14) was gained from the $T_{1}$ treatment potato under mango-based agroforestry system while the minimum benefit-cost ratio (1.78) was taken in the $\mathrm{T}_{0}$ potato growing in mono farming practice.

\section{Materials and methods}

\section{Plant materials}

The 10 years old mango (variety BARI Am 3 Amropali) orchard has been used for the present research work. The plant to plant and row to row distance of these mango trees was 5 meters with east-west plant geometry. The average mango tree height, basal diameter and crown diameter was found 4.92 meter, $6.53 \mathrm{~cm}$ and $175 \mathrm{~cm}$, respectively. The cardinal variety of seed tubers was the research testing crop. It was collected from the authentic marketing division of Bangladesh Agricultural Development Corporation (BADC).

\section{Experimental sites and description}

The experiment was conducted in the research field at the department of Agroforestry \& Environment Hajee Mohammad Danesh Science and Technology University, Dinajpur, Bangladesh. It was located between latitude 250 $13^{\prime}$ \& longitude $88^{\circ} 23^{\prime}$ and $37.5 \mathrm{~m}$ above sea level. The soil of the experimental plot was mainly sandy loam (mixture of sand $67 \%$, silt $33 \%$ and clay $5 \%$ ), having organic matter (1.25\%) with $\mathrm{pH}(5.1)$ and also the chemical properties such as total nitrogen $(0.12 \%)$, sodium $(0.05 \mathrm{meq} / 100 \mathrm{~g})$, calcium $(1.33 \mathrm{meq} / 100 \mathrm{~g})$, magnesium $(0.41 \mathrm{meq} / 100 \mathrm{~g})$, potassium $(0.25 \mathrm{meq} / 100 \mathrm{~g})$, phosphorus $(25.0 \mu \mathrm{g} / \mathrm{g})$, sulphur $(3.1 \mu \mathrm{g} / \mathrm{g})$, boron $(0.28 \mu \mathrm{g} / \mathrm{g})$, iron $(5.30 \mu \mathrm{g} / \mathrm{g})$, zinc $(0.90 \mu \mathrm{g} / \mathrm{g})$ and CEC $(8.0 \mathrm{meq} / 100 \mathrm{~g})$. The climate of the experimental site was quite good. The maximum average temperature $\left(30.1^{\circ} \mathrm{C}\right)$, minimum average temperature $\left(18.30{ }^{\circ} \mathrm{C}\right.$ ), average mean temperature $\left(23.15{ }^{\circ} \mathrm{C}\right)$, no rainfall, average relative humidity $(89.00 \%)$ and sunshine $(5.6 \mathrm{hrs})$ was observed in November 2018. A slightly reduce in maximum, minimum and mean temperature, no rainfall average relative humidity (85.00\%) and sunshine (4.8 hrs) was recorded in December 2018. In the next month January 2019, it was found cold environment temperature fall 8.5 an average $15.4{ }^{\circ} \mathrm{C}$, no rainfall, humidity $92 \%$ and sunshine 4.2 hrs.

\section{Experimental design}

The experiment was laid out following a split plot design with three (3) replications. Potato production system under mango orchard and open field were arranged in main plots $\mathrm{T}_{0}=$ potato sole cropping (control) and $\mathrm{T}_{1}=$ potato under mango-based agroforestry system. On the other hand, potato intra-row plant spacing were in sub-plots $S_{0}=60 \times 20$ $\mathrm{cm}^{2}, \mathrm{~S}_{1}=60 \times 25 \mathrm{~cm}^{2}$ and $\mathrm{S}_{2}=60 \times 30 \mathrm{~cm}^{2}$. Hence, the system-spacing treatment combinations were; $\mathrm{T}_{0} \mathrm{~S}_{0}=60 \times 20$ $\mathrm{cm}^{2}$ intra-row spacing of potato in sole cropping, $\mathrm{T}_{0} \mathrm{~S}_{1}=60 \mathrm{x}$ $25 \mathrm{~cm}^{2}$ intra-row spacing of potato in sole cropping, $T_{0} S_{2}=$ $60 \times 30 \mathrm{~cm}^{2}$ intra-row spacing of potato in sole cropping, $T_{1} S_{0}$ $=60 \times 20 \mathrm{~cm}^{2}$ intra-row spacing of potato mango-based agroforestry system, $\mathrm{T}_{1} \mathrm{~S}_{1}=60 \times 25 \mathrm{~cm}^{2}$ intra-row spacing of potato under mango-based agroforestry system and $\mathrm{T}_{1} \mathrm{~S}_{2}=$ $60 \times 30 \mathrm{~cm}^{2}$ intra-row spacing in potato under mango-based 
agroforestry system. The total numbers of experimental plots were 18. The individual plot area was $4.5 \mathrm{~m} \times 4.5 \mathrm{~m}=$ $20.25 \mathrm{~m}^{2}$. Nine (9) plots were laid under the mango orchard and 9 plots were laid in the control (open field). The field research work was started in November 2018 and was completed in March 2019.

\section{Crop establishment}

The land in the experimental plots was ploughed using a tillage machine on 30 November 2018. The corners of the land not reached by the tillage machine were dug with a spade, and visibly larger clods were hammered to break them into small pieces. All weeds and stubble were removed from the field. The layout was prepared according to the experimental design and made ready for planting. The wellsprouted seed tubers were planted on the 12 December 2018 at a depth of $10 \mathrm{~cm}$ in furrows $60 \mathrm{~cm}$ apart with spacings of $20 \mathrm{~cm}, 25 \mathrm{~cm}$ and $30 \mathrm{~cm}$ in each line according to which treatment they represented. Therefore, the 210 seed potato tubers were planted in each $T_{1} S_{0}$ plot, 168 tubers in each $\mathrm{T}_{1} \mathrm{~S}_{1}$ plot, 140 tubers in each $\mathrm{T}_{1} \mathrm{~S}_{2}$ plot, 240 tubers in each $\mathrm{T}_{0} \mathrm{~S}_{0}$ plot, 192 tubers in each $\mathrm{T}_{0} \mathrm{~S}_{1}$ plot and 160 tubers in each $\mathrm{T}_{0} \mathrm{~S}_{2}$ plot.

\section{Fertilizer application and after care}

The plant nutrients organic matter, $\mathrm{N}, \mathrm{P}_{2} \mathrm{O}_{5}, \mathrm{~K}_{2} \mathrm{O}$ were supplied in the form of dried cow-dung 4.5 tonnes per ha, Urea $150.0 \mathrm{~kg}$ per ha, TSP $100.0 \mathrm{~kg}$ per ha and MP $160.0 \mathrm{~kg}$ per ha. Half of Urea and full doses of cow-dung, TSP, MP were applied as the basal dose in furrows made on both sides of the seed rows and mixed properly with soil at planting time. In addition, the remaining urea was applied at 40 DAP during the second earthing-up at the side of the rows and covered with soil. Three irrigations were provided throughout the growing period. The first one was done at 30 days after planting. Subsequently, two irrigations were given at 20 days interval. After each irrigation, the soil was mulched by breaking the crust for aeration and to conserve soil moisture. Manual weeding was done as and when necessary to keep the plots completely free from all weeds. Earthing up was done at 25 days and 40 days after planting.

\section{Data collection}

From the experiment, germination percentage, plant height, leaf length, leaf breadth, number of shoots per hill, numbers of potato tubers per hill, weight of potato tubers per hill, tuber yield of potato, dry matter and tuber grade data were recorded. For the economic performance of the production systems, the economic yield of potato and mango was calculated by production cost, gross \& net returns and benefit-cost ratio. The production cost, gross $\&$ net returns were calculated based on the prevailing market prices and transformed into United States dollars.

\section{Statistical analysis}

The statistical test ANOVA (Analysis of Variance) was done with the help of the SPSS (22.0) statistical data analysis software while the data mean separations were adjusted by the DMRT (Duncan's Multiple Range Test) (Gomez and Gomez, 1984).

\section{Conclusion}

Agroforestry practices facilitates to ensure sustainable crop production by increasing soil organic matter, maintaining proper management, diminishing the hazard of crop losses, confirming the highest utilization of natural resources. It creates a balanced and sustainable production system. The findings from experimental results reveal that potatoes can cultivate the most under the mango-based agroforestry system with the closest $\left(60 \times 20 \mathrm{~cm}^{2}\right)$ intra-row plant spacing for better yield. Potato under mango-based agroforestry practice brings a positive significant return of money using the pitch of land. In conclusion, the research finding indicates the benefit-cost ratio (2.14) from the combined cultivation of potatoes and mangos which was $20 \%$ higher than growing potatoes as a sole crop. This production technique ensures not only the food safety, but also increases the income of the farmers and ensures the longterm sustainability.

\section{Acknowledgements}

The authors would like to appreciate at Research and Development (RDO). Prince of Songkla University, Thailand through to the grant number ENV6402012N.

\section{References}

AIS (2014) Orthobosore Nirdharito Lokkhomatra O Orjon. Krishi Diary, Agricultural Information Service. Department of Agricultural Extension (DAE), Bangladesh.

Arega A, Tekalign A, Solomon T, Tekile B (2018) Effect of inter and intra row spacing on tuber yield and yield components of potato (Solanum tuberosum L.) in Guji zone, Southern Ethiopia. J Adv Plant Sci. 1: 102.

Akassa B, Belew D, Debela A (2014) Effect of inter and intra row spacing on potato (Solanum tuberosum L.) seed and ware tuber seedling emergence and establishment at Bako, Western Ethiopia. J Agron. 13(3):127-130.

Ali MM, Rahman MM, Islam S, Islam MA, Alam MR, Bari MS, Nahar MN (2018) Varietal performance of turmeric under mango-based agroforestry system. Am J Plant Sci. 9:9951003.

Amin MHA, Roy JP, Rahman MS, Kajal M (2017) Economic performance of onion under Albizia lebbeck, Melia azedarach and Leucaena leucocephala based agroforestry systems. J Innov Dev Strategy. 11(1):1-8.

Bargali SS, Bargali K, Singh L, Ghosh L, Lakhera ML (2009) Acacia nilotica based traditional agroforestry system: effect on paddy crop and management. Curr Sci India. 96(4):581-587.

Bargali SS, Singh SP, Pandya KS (2004) Effects of Acacia nilotica on gram crop in a traditional agroforestry system of Chhattisgarh plains. Int J Ecol Environ Sci. 30(4):363368.

BBS (2018) Population Census. Bangladesh Bureau of Statistics. Ministry of Planning, Government of the People's Republic of Bangladesh, Dhaka, Bangladesh.

BBS (2017) Yearbook of agricultural statistics-2017. Bangladesh Bureau of Statistics. Ministry of Planning. Government of the People's Republic of Bangladesh, Dhaka, Bangladesh.

Bernik R, Godesa T, Ferencak B, Vucajnk F (2002) The influence of inter-row width in potato production 
(Solanum tuberosum L.) on quantity of market yield. Kmetijstvo (Agronomija). 79(2):371-379.

Bussan AJ, Mitchell PD, Copas ME, Drilias MJ (2007) Evaluation of the effect of density on potato yield and tuber size distribution. Crop Sci. 47(6): 2462-2472.

Chowdhury MK (1997) Agroforestry in homesteads and croplands: existing practices and potentials. In: Alam MK, Ahmed FU, Amin SMR (eds) Agroforestry: Bangladesh perspectives. Bangladesh Agricultural Research Council, Dhaka, pp 68-84.

Dagar J, Singh G (2004) Evaluation of crops in agroforestry with Casuarina equisetifolia (Linn.) plantations. Indian J For. 3(1):47-50.

Demagante AL, Vander Zaag $P$ (1988). The response of potato (Solanum spp.) to photoperiod and light intensity under high temperatures. Potato Res. 31(1): 73-83.

Garrity DP, Mercado Jr A, Solera C (1992) The nature of species interference and soil changes in contour hedge row systems on sloping acidic lands. Paper presented at the International Conference on Alley Farming, IITA Ibadan Nigeria, 14-18 September 1992.

Gaur PC, Pandey SK (1993) True Potato Seed (TPS) Technology. Adv Hort. 7: 85-111.

Getachew T, Belew D, Tulu S (2012) Yield and growth parameters of potato (Solanum tuberosum L.) as influenced by intra row spacing and time of earthing up: In Boneya Degem District, Central Highlands of Ethiopia. Int J Agric Res. 7 (5): 255-265.

Gomez KA, Gomez AA (1984) Statistical procedures for agricultural research, 2nd edn. John Wiley and Sons, New York.

Hirpa A, Meuwissen MP, Tesfaye A, Lommen WJ, Lansink AO, Tsegaye A, Struik PC (2010) Analysis of seed potato systems in Ethiopia. Am J Pot Res. 87(6):537-52.

Islam MS, Moonmoon S, Islam MZ, Waliullah H, Hossain MS (2012) Studies on seed size and spacing for optimum yield of potato in northern region of Bangladesh. Bangladesh J Prog Sci \& Tech. 10(1):113-116.

Kajal M, Amin MHA, Bari MS, Zaman MR, Hanif MA (2015) Varietal performance of transplanted aman rice under mango-based agroforestry system. J Agrofor Environ. 9 (1 \& 2):41-44.

Kövendi-Jakó A, Csecserits A, Halassy M, Halász K, Szitár K, Török K (2017) Relationship of germination and establishment for twelve plant species in restored dry grassland. Appl Ecol Env Res. 15(4):227-239.

Kirk WW, Marshall B (1992). The influence of temperature on leaf development and growth in potatoes in controlled environments. Ann Appl Biol. 120(3):511-525.
Kumar A, Nandal DP (2004) Performance of winter crops under Eucalyptus tereticornis based agri silviculture system. Indian J Agrofor. 6(2):97-98.

Miah MG, Ahmed FU, Ahmed MM, Alam MN, Choudhury $\mathrm{NH}$, Hamid MA (2002) Agroforestry in Bangladesh: Potentials and opportunities. Paper presented in South Asia Regional Agroforestry Consultation workshop, New Delhi, India, 23-25 November 2002.

Nandal DP, Hooda MS (2005) Production potentials of some agricultural crops under different spacings of poplar. Indian J Agrofor. 7(1):16-20.

Padalia K, Bargali K, Bargali SS (2015) How does traditional home-gardens support ethnomedicinal values in Kumaun Himalayan Bhabhar belt, India? Afr J Tradit Complem. 12(6):100-112.

Pandey K, Bargali SS, Kolhe SS (2011) Adoption of technology by rural women in rice based agroecosystem. Int Rice Res Notes. 36:1-4.

Rahman MA, Gaffer MA (1991) Effect of spacing on the yield of potato. Bangladesh J Sci Indus Res. 26(1-4):200-203.

Rahman MH, Rahman MM, Bari MS, Islam MR, Quraishy MA (2016) Varietal performance of napier fodder (Pennisetum purpureum) influenced by nitrogen fertilizer under mangobased agroforestry system. Int J Plant Soil Sci. 13(2):1-6.

Solomon-Blackburn RM, Barker H (2001) Breeding virus resistant potatoes (Solanum tuberosum): a review of traditional and molecular approaches. Heredity. 86(1):1735.

Sultana N, Siddique A (1991). Effects of cut seed piece and plant spacing on the yield and profitability of potato. Bangladesh Hort. 19(1):37-43.

Wolf S, Marani A, Rudich J (1990) Effects of temperature and photoperiod on assimilate partitioning in potato plants. Ann Bot. 66(5):513-520.

Yenagi BS, Meli SS, Angadi SS (2010). Effect of row spacing, planting date and nitrogen level on tuber grade, yield and economics of potato. Karnataka J Agri Sci. 17(2):220-223.

Zaman MR, Bari MS, Kajal M, Firoz HM (2016). Potentiality of litchi-fodder based agroforestry system in Bangladesh. J Food Nutr Res. 4(2):76-81.

Zamil MF, Rahman MM, Rabbani MG, Khatun T (2010) Combined effect of nitrogen and plant spacing on the growth and yield of potato with economic performance. Bangladesh Res Pub J. 3(3):1062-1070. 